\title{
A Study of Coupling Relationship between Financial Supervision and Innovation: Based on the Data of China's Commercial Bank Listed in the Form of A Shares
}

\author{
Wei Song ${ }^{1}$, Chao Yan ${ }^{1,2}$, Xiaobao Peng ${ }^{1}$, Shanshan Zheng ${ }^{1}$ \\ ${ }^{1}$ School of Public Affairs, University of Science and Technology of China, Hefei, China \\ ${ }^{2}$ Retail Business Department, Jiangsu Zijin Rural Commercial Bank Co., Ltd., Nanjing, China \\ Email: $\underline{369652846 @ q q . c o m}$
}

Received 8 December 2014; accepted 7 February 2015; published 11 February 2015

Copyright (C) 2015 by authors and Scientific Research Publishing Inc.

This work is licensed under the Creative Commons Attribution International License (CC BY). http://creativecommons.org/licenses/by/4.0/

\section{(c) (i) Open Access}

\begin{abstract}
Financial supervision and financial innovation of commercial banks are the two eternal themes of modern financial development, the research of relationship between financial supervision and innovation has become the focus of financial sector research. Based on the study of financial supervision and innovation index of commercial banks, this paper establishes a coupling model for financial supervision and innovation of commercial banks and conducts an empirical research based on data contained annual reports of commercial banks listed in the form of A Shares, with results showing that financial supervision and innovation of domestic listed commercial banks are at the stage of moderate coupling, upon which relevant suggestions are concluded.
\end{abstract}

\section{Keywords}

Commercial Banks, Financial Supervision, Financial Innovation, Coupling Degree, Entropy Weighting Method

\section{Introduction}

In broad sense, financial supervision of commercial bank refers to supervision on commercial bank and relevant shareholders, directors, affiliated person and other subjects from government supervisory authorities, banking self-regulatory organizations, social intermediary organizations and other commercial bank supervision subjects. This supervision ensures the steady operation of the whole banking system to prevent the whole financial indus- 
try from being affected by bank crisis. In narrow sense, financial supervision of commercial bank refers to supervision on commercial bank from banking supervisory subjects, which is the theme in this work. The supervision may lead commercial banks to improve internal control system and realize steady operation by supervising indicators, including capital sufficiency, assets and liabilities and risk management. Financial innovation of commercial bank refers to various new activities developed by commercial banks in aspects of strategic decision, institutional arrangement, institution setting, personnel preparation, management model, business process and financial products by means of new technology introduction, new method adoption, new market exploration and new organization construction to adapt economic development requirements (CBRC, 2006). The final reflections are the increasing risk management ability of bank, as well as innovation and update for service products and methods for customers. In broad sense, financial innovation of commercial bank refers to all banking innovative activities in financial fields of products, market, system, etc., while in narrow sense, it refers to innovation in financial products and business of commercial bank, which is the theme in this work.

Researches by large amount of scholars indicate that there is an obvious relation between financial supervision and financial innovation of commercial bank. Kane established "Fight Model" to describe endless fight between supervisor and the supervised. He thought that government supervision was a recessive tax bearing for financial institution, which would increase cost of financial institute. The government will enhance supervision when financial institute is crazy about realizing profit maximization through financial innovation to reduce cost, while innovation has adverse effects on financial system (Kane, 1981). Silber put forward "Hypothesis of Restrain inducing innovation”, which regards financial innovation as "self-defense” behavior by financial institute to get rid of or reduce financial control of government and other foreign organizations. This emphasizes the key cause of financial innovation is financial supervision (Silber, 1983). Miller also regarded financial supervision and taxation as the major force for driving financial innovation (Miller, 1986). Moreover, Finnerty further proved the high correlation between financial supervision and financial innovation of bank (Finnerty, 1993). Isik \& Hassan considered that financial innovation with high lever ratio may intensify various risks more easily. Loose financial supervision may cause excessive financial innovation and sharp increase of market risk. Finally, it is hard to avoid impacts on financial market because of these risks, and the financial system may be unstable (Isik \& Hassan, 2003). Xun Tao regarded financial supervision and innovation as a contradictory unity. The relation between financial supervision and innovation is finally reflected by the relation between financial efficiency and financial safety (Xun Tao, 2002). Liang Shuxia thought that the relation between financial supervision and innovation is interactive. Financial innovation may increase the difficulty of financial supervision, and further drive the adjustment of financial supervision system (Liang, 2002). Li Yangyong considered that innovation of financial supervision is a part of financial innovation. Therefore, financial supervision and innovation are not unity of opposites. Financial supervision shall continuously innovate to adapt age requirements and promote deep development of various innovative activities in financial fields (Li, 2004). Zheng Li thought that the relation between financial supervision and innovation was a dynamic game relation, and suggested financial supervision authority to change supervision concept, apply modern information technology and improve supervision system by adapting new situation in current to prevent financial risk (Zheng, 2006). Zhu Mingxing selected data of listed commercial banks in Shanghai and Shenzhen Exchange during 2007-2011 to study the correlation between innovation capacity and risk supervision index of commercial bank. The result shows that innovation capability of commercial bank is negatively related to non-performing loan ratio, and positively related to capital adequacy ratio and loan-to-deposit ratio. However, liquidity ratio has no obvious effects on innovation capability (Zhu, 2013). According to the review of domestic and foreign literature, theoretical discussion is more than empirical study among studies on relationship between financial supervision and financial innovation. At the same time, the deep research on interaction effects is quite little. This work studies the relationship between them by coupling model in physics, and constructs coupling relation model in theory. Moreover, this work makes empirical analysis on the interaction effects and puts forward relevant suggestions for promoting coupling development according to data of commercial banks listed as A-stock in recent years.

\section{Coupling Mechanism Analysis on Financial Supervision and Financial Innovation of Commercial Bank}

In physics, coupling theory refers to the mechanism that two or more than two systems or motion forms affect each other by various interaction, and coupling relation to dynamic incidence relation of mutual promotion, coordination and influence for benign interaction among subsystems. American scholar Weick was the first to 
adopt coupling theory in study on economic and social problems. He used loose coupling theory to explain relation among members of schools and organizations, who are interrelated but also independent (Weick, 1976). At present, this theory has been widely adopted to explain interrelation among two or more economic phenomena affecting each other for a certain condition. This work defines phenomenon that interaction between financial supervision and financial innovation in market economy through respective coupling elements as coupling between financial supervision and financial innovation of commercial bank. This work considers the relation between financial supervision and financial innovation of commercial bank is coupling relation. According to relevant definition of coupling and literature review, this work puts forward three mechanisms for realizing coupling.

Financial supervision and financial innovation of commercial bank form cause and fact coupling relation in initial stage. All the financial innovation can't change the natures of commercial bank, including high lever, information asymmetry and external effects, so supervision shall be done for commercial banks and financial innovation at the beginning. Financial supervision makes control to capital adequacy, structure of assets and liabilities, risk management, etc. of commercial bank, which leads cost increase. Commercial banks will reduce cost and enhance competitiveness by innovation method of exploring new financial tools and products. Therefore, cause and coupling relation between financial supervision and financial innovation is formed in initial stage.

Financial supervision and financial innovation of commercial bank will evolve with time by dynamic game mechanism to form a dynamic game coupling relationship. In recent years, China banking develops rapidly, during which financial innovation of commercial banks constantly evolves from on- to off-balance sheet items, from single to multiple business, from traditional to newly-developing business. At the same time, financial supervision has to innovate the supervision in order to adapt endless financial innovation by commercial banks, from institution supervision to function supervision, from capital supervision to comprehensive risk supervision, from external to internal control system enhancement, etc. During the evolvement, newly-developed financial innovation and financial supervision emerge endless to form dynamic game mechanism between both.

The result for dynamic game evolvement of both financial supervision and financial innovation of commercial banks is driving the development of both to form a coupling relationship of mutual promotion. Emergence of financial innovation of commercial bank is making the bound between bank and non-banking financial institutes, as well as currency assets and financial assets vaguer and vaguer. Therefore, basic conditions for financial supervision operation changes, and finally supervision is stimulated. In addition, financial supervision make innovative financial tools understandable to provide credit security to innovative financial products, and promote financial innovation development. Finally, more and more financial innovation will form to make financial supervision increasing and promoting with financial innovation mutually. Therefore, the coupling relationship of mutual promotion between both will be formed.

In conclusion, financial supervision and financial innovation of commercial banks may jointly develop with time by cause coupling, game coupling and coupling mechanism of mutual promotion. This coupling mechanism of "supervision—innovation—re-supervision—re-innovation" will promote deep development for financial activities of commercial banks.

\section{Coupling Theory and Model of Financial Supervision and Financial Innovation of Commercial Banks}

\subsection{Coupling Function Model}

Coupling theory defines coupling function with effect function, where, $u_{i}(1 \leq i \leq n)$ is the order parameter in coupling system of financial supervision and financial innovation of commercial bank, $u_{i j}$ is $j$ th index of $i$ th order parameter with value of $x_{i j}(1 \leq j \leq m)$, and $\alpha_{i j}, \beta_{i j}$ are upper limit and lower limit of stable order parameter in coupling system, respectively, that is $\alpha_{i j}=\max \left(\mathrm{x}_{i j}\right)$ and $\beta_{i j}=\min \left(\mathrm{x}_{i j}\right)$. Effect function is expressed as follows:

$$
u_{i j}=\left\{\begin{array}{lr}
\left(x_{i j}-\beta_{i j}\right) /\left(\alpha_{i j}-\beta_{i j}\right) u_{i j} & \text { Positive effect, playing positive role in system } \\
\left(\alpha_{i j}-x_{i j}\right) /\left(\alpha_{i j}-\beta_{i j}\right) u_{i j} & \text { Negative effect, playing negative role in system }
\end{array}\right.
$$


$u_{i j}$ is the contribution of variable $x_{i j}$ to system function. When $u_{i j}$ tends to be 0 , the contribution of $x_{i j}$ is the most dissatisfied to system. When $u_{i j}$ tends to be 1 , the contribution of $x_{i j}$ is the most satisfied to system. Therefore, it can be concluded that $0 \leq u_{i j} \leq 1$. In addition, coupling system of financial supervision and financial innovation of commercial bank has respective subsystems for both financial supervision and financial innovation as support. The contribution of order parameters in subsystems can be realized by integration, which uses linear weighting summation in general:

$$
u_{i}=\sum_{i=1}^{n} \lambda_{i j} u_{i j}, \sum_{j=1}^{m} \lambda_{i j}=1
$$

$u_{i}$ presents the contribution of subsystem to overall system with index weight, $\lambda_{i j}$. This work will determine $u_{i}$ by entropy weighting method. After determining the effect of order parameter, following coupling function between financial supervision and financial innovation of commercial bank can be obtained by volume coupling concept and coupling coefficient model:

$$
C=\left\{\left(u_{1} \cdot u_{2}\right) /\left[\left(u_{1}+u_{2}\right)\left(u_{1}+u_{2}\right)\right]\right\}^{1 / 2}
$$

According to this coupling function, coupling degree $C \in[0,1)$, which means: When $C=0$, order parameters are unrelated with each other, and the system realizes negative emergence to become disordered. The steady operation of commercial bank will not be improved because of development of financial supervision and financial innovation. When $0<C \leq 0.33$, the coupling coordination between financial supervision and financial innovation of commercial bank is relatively low, and financial innovation of commercial banks is lack of effective regulatory security or excessive in financial supervision measures to make innovation weak. When $0.33<C \leq$ 0.66, the coupling coordination between financial supervision and financial innovation of commercial bank is moderate, and financial supervision and financial innovation need to match with each other in scale, structure, etc. When $0.66<C<1$, the coupling coordination between financial supervision and financial innovation is high, and benign coupling coordinated development with mutual promotion between both is basically realized. Therefore, the development of both financial supervision and financial innovation are in spiral escalation, and banking can develop orderly and healthily. When $C$ tends to be1, the coupling degree between financial supervision and financial innovation of commercial bank is the highest, benign resonance coupling among order parameters is realized, the system is in benign emergence, and steady operation level of commercial banks is greatly improved.

\subsection{Determination of Evaluation Index System for Coupling Degree}

In order to quantize the coupling degree between financial supervision and financial innovation of commercial bank, this work establishes an evaluation index system reflecting coupling degree between both by combining relevant supervision index and operating management index required for information disclosure of A-stock listed commercial banks by national security system in index selection principle of scientific and reasonable, comprehensive and objective, as well as operable. Evaluation index system for financial supervision of commercial bank is mainly dependent on the "CARPALS" supervision index system of China Banking Regulatory Commission, (Dang \& Xiang, 2012) and learns lessons of financial crisis and integrates advanced supervision concept in Basel Accord III. This system is composed of indices of capital adequacy, asset quality, risk concentration, provisioning coverage, affiliated institutions, liquidity, and Sle prevention control. This work reflects the supervision on bank capital adequacy with core capital adequacy ratio, risk concentration with top single customer's loan ratio, asset quality with non-performing loan ratio, provisioning coverage with provisioning coverage ratio, and liquidity condition by deposit-to-loan ratio. Therefore, the effectiveness of supervision on commercial banks can be reflected comprehensively.

The income structure of commercial bank can reflect its financial innovation level. At present, major income source of national commercial bank is interest spreads of deposit and loan. On one hand, it shows that domestic commercial banks are short of financial innovative power, and income from intermediate business, except interest spreads of deposit and loan, has become the key index for measuring financial innovation of domestic com- 
mercial banks. On the other hand, with technological development, financial disintermediation, relax control and intense market competition, exploration of intermediate business and development of innovative products have become mainstream gradually in European and American developed countries. At the same time, commercial banks in Asia-Pacific region will copy the development track of European and American banks in income structure to some extent. At present, financial innovation for domestic commercial banks mainly concentrates on financial services, bank card business, agent service, etc. Moreover, supervision staff also take income of intermediate business as an important index for measuring financial innovation of commercial bank (Zhu \& Li, 2011). This work measures the quality of financial innovation by indices of the percentage of non-interest income and the weighted average return on equity and the speed by the growth rate of the percentage non-interest income and the growth rate of average return on equity. Therefore, financial innovation of commercial bank can be reflected comprehensively. Finally, this work establishes an evaluation index system with core capital adequacy ratio, non-performing loan ratio, top single customer's loan ratio, non-performing loan ratio, provisioning coverage ratio, deposit-to-loan ratio (RMB), the percentage of non-interest income, the weighted average return on equity, the growth rate of the percentage non-interest income, the growth rate of average return on equity (see in Table 1).

\subsection{Judging the Weight of Order Parameter through the Entropy Weighting Method}

As an objective weighting method, the entropy weighting method aims to judge the effectiveness and value of coupling degree evaluation indexes by using the subjective factors. In the process of entropy weighting, we have conducted standardization and normalization processing to data through the power function (3.1) (Sun, Xing, \& Zhou, 2010), thus deriving a matrix

Table 1. Index system for coupling relation between financial supervision and financial innovation of commercial bank.

\begin{tabular}{|c|c|c|}
\hline $\begin{array}{l}\text { Order } \\
\text { parameter } \\
\text { of system }\end{array}$ & $\begin{array}{l}\text { Order parameter } \\
\text { of subsystem }\end{array}$ & Definition of order parameter index \\
\hline \multirow{5}{*}{$\begin{array}{l}\text { Financial } \\
\text { supervision }\end{array}$} & $\begin{array}{c}\text { Core capital } \\
\text { adequacy ratio }\end{array}$ & $\begin{array}{l}\text { Compared with risk weighting assets, core capital is an important index for measuring } \\
\text { reputation and economic strength of commercial bank. The higher this index, } \\
\text { the more effective the financial supervision of commercial bank will be. }\end{array}$ \\
\hline & $\begin{array}{l}\text { Non-performing } \\
\text { loan ratio }\end{array}$ & $\begin{array}{l}\text { Compared with total loan, non-performing loan ratio is an important index for } \\
\text { evaluating safety of commercial bank credit assets. The higher this index, } \\
\text { the invalid the financial supervision of commercial bank will be. }\end{array}$ \\
\hline & $\begin{array}{l}\text { Top single } \\
\text { customer's } \\
\text { loan ratio }\end{array}$ & $\begin{array}{l}\text { Ratio between loan balances of the same borrow and bank capital balance. } \\
\text { High index may make risk of commercial bank too concentrated to } \\
\text { affect operation safety and lead financial supervision invalid. }\end{array}$ \\
\hline & $\begin{array}{l}\text { Provisioning } \\
\text { coverage ratio }\end{array}$ & $\begin{array}{l}\text { Ratio between actual withdrawing loan loss reserve and non-performing loan. This ratio is } \\
\text { an important index for measuring if the loan loss reserve of commercial bank is sufficient. } \\
\text { The higher this index, the more effective the financial supervision of commercial bank will be. }\end{array}$ \\
\hline & $\begin{array}{l}\text { Deposit-to-loan } \\
\text { ratio }(\mathrm{RMB})\end{array}$ & $\begin{array}{l}\text { Ratio between total loan in RMB and total deposit in RMB. The lower this index, the stronger } \\
\text { the liquidity of commercial bank and the more effective the financial supervision will be. }\end{array}$ \\
\hline \multirow{4}{*}{$\begin{array}{l}\text { Financial } \\
\text { innovation }\end{array}$} & $\begin{array}{l}\text { The percentage } \\
\text { of non-interest } \\
\text { income }\end{array}$ & $\begin{array}{l}\text { Ratio between the sum of handling charge and non-interest income of net income of commission, } \\
\text { income of other businesses and investment and operating income. This ratio may directly } \\
\text { measure the earning capacity of commercial bank except income from interest rate differential. } \\
\text { The higher this index, the stronger the financial innovative capacity of commercial bank will be. }\end{array}$ \\
\hline & $\begin{array}{l}\text { The weighted } \\
\text { average return } \\
\text { on equity }\end{array}$ & $\begin{array}{l}\text { Ratio between net profit after tax and average net assets. The higher this ratio, the better } \\
\text { the economic benefit of self-investment, the stronger the earning capacity except } \\
\text { income from interest rate differential, and stronger the innovative capacity will be. }\end{array}$ \\
\hline & $\begin{array}{l}\text { The growth rate } \\
\text { of the percentage } \\
\text { non-interest income }\end{array}$ & $\begin{array}{l}\text { This ratio reflects the growth rate of non-interest income share of commercial and } \\
\text { innovation speed of commercial bank. The higher this index, the stronger } \\
\text { the innovative capacity of commercial bank will be. }\end{array}$ \\
\hline & $\begin{array}{l}\text { The growth rate of } \\
\text { the weighted average } \\
\text { return on equity }\end{array}$ & $\begin{array}{l}\text { This ratio reflects the growth rate of weighted average net assets returns ratio and } \\
\text { innovation speed of commercial bank. The higher this index, the stronger } \\
\text { the innovative capacity of commercial bank will be. }\end{array}$ \\
\hline
\end{tabular}




$$
U=\left(\mathrm{u}_{i j}\right)_{n \times m}
$$

In order to avoid taking the logarithm meaninglessly while deriving the entropy, we have ordered

$$
X=\left(u_{i j}+1\right)_{n \times m}=\left(x_{i j}\right)_{n \times m},(1 \leq \mathrm{i} \leq n ; 1 \leq j \leq m)
$$

and horizontally moved the data, and transformed the actual value of evaluation indexes into the evaluation value through the formula:

$$
\mathrm{P}_{i j}=\frac{x_{i j}}{\sum_{j=1}^{m} x_{i j}},(1 \leq \mathrm{i} \leq n ; 1 \leq j \leq m)
$$

namely: calculating the percentage of the No. $i$ bank in this index under the No. $j$ index. Through the formula:

$$
e_{j}=k / \sum_{j=1}^{m} p_{i j} \ln \left(p_{i j}\right), \mathrm{k} \succ 0, k=\frac{1}{\ln (\mathrm{n})}, e_{j} \succ 0
$$

we have calculated the entropy of the No. $j$ index. Through the formula,

$$
g_{j}=\frac{1-e_{j}}{m-E_{e}}, E_{e}=\sum_{j=1}^{m} e_{j}, 0 \leq g_{j} \leq 1, \sum_{j=1}^{m} g_{j}=1
$$

we have derived the diversity factor of the No. $j$, and eventually derived the weight to be,

$$
W_{j}=\frac{g_{j}}{\sum_{j=1}^{m} g_{j}},(1 \leq j \leq m)
$$

\section{Empirical Study on Coupling Coordination Degree of Chinese Listed Commercial Banks}

Up to September 2014, there are 16 A-stock listed commercial banks in china, including 5large-scale stateowned commercial banks, such as Industrial and Commercial Bank of China (ICBC), China Construction Bank (CCB), Bank of China (BOC), Bank of Communications (BOCOM) and Agricultural Bank of China (ABC); 8 joint-stock commercial banks, such as China Merchants Bank (CMBC), Shanghai Pudong Development Bank (SPDB), China Minsheng Bank (CMSB), Ping'an Bank (PAB), Industrial Bank (CIB), Hua Xia Bank (HXB), China Citic Bank (CCITICB) and China Everbright Bank (CEB); and 3 city commercial banks, such as Bank of Beijing (BOBJ), Bank of Nanjing (NJCB) and Bank of Ningbo (NBCB). We obtain evaluation index data for coupling degree of these 16 banks in 2009, 2011 and 2013 by WIND database and bank annual report (See in Table 2). A-stock listed commercial banks, which are more standard in company governance, operation management and information disclosure, represent overall business capacity and future development direction of domestic banking. Therefore, it has a certain guiding significance in improving overall competitiveness of domestic banking to study the coupling relation between financial supervision and financial innovation of listed commercial banks.

Non-interest income share, growth rate of non-interest income share, weighted average net asset income rate, growth rate of weighted average net asset income rate and core capital adequacy ratio are positive effect indices, which play a positive role in development of subsystem. Non-performing loan ratio, loan-to-deposit ratio and proportion of loan from single largest customer are negative effect indices, which play a negative role in development of subsystem. According to effect function Formula (3.1), we establish a matrix, and unify and optimize all the positive and negative effect indices to obtain Matrix $U_{11 \times 16}$. In order to avoid meaningless logarithm when getting entropy, we will translate data with Formula (3.4), translate actual value of evaluation index into evaluation value with Formula (3.5), and then calculate the entropy of jth index with Formula (3.6). Finally, we can obtain all the index weights by calculating $j_{\text {th }}$ diversity factor with Formula (3.7) and (3.8) (see in Table 3).

Contribution value $u_{i j}$ of subsystem order parameter can be obtained after unifying and optimizing all the positive and negative effect indices by establishing matrix with effect function Formula (3.1). Order parameters $u_{1}$ and $u_{2}$ can be calculated with order parameter weights obtained with Formula (3.2) and entropy weighting method. Eventually, coupling degree c of each system can be obtained with Formula (3.3) (see in Table 4). 
Table 2. Index of coupling degree between financial supervision and financial innovation of commercial bank.

\begin{tabular}{|c|c|c|c|c|c|c|c|c|c|c|}
\hline \multirow[b]{2}{*}{$\begin{array}{c}\text { Order } \\
\text { parameter } \\
\text { commercial } \\
\text { bank }\end{array}$} & \multirow[b]{2}{*}{$\begin{array}{c}\text { Date } \\
\text { (Year) }\end{array}$} & \multicolumn{5}{|c|}{ Financial supervision } & \multicolumn{4}{|c|}{ Financial innovation } \\
\hline & & $\begin{array}{c}\text { Core } \\
\text { capital } \\
\text { adequacy } \\
\text { ratio }\end{array}$ & $\begin{array}{l}\text { Non- } \\
\text { performing } \\
\text { loan ratio }\end{array}$ & $\begin{array}{c}\text { Top } \\
\text { single } \\
\text { customer's } \\
\text { loan } \\
\text { ratio }\end{array}$ & $\begin{array}{l}\text { Provisioning } \\
\text { coverage } \\
\text { ratio }\end{array}$ & $\begin{array}{l}\text { Deposit- } \\
\text { to-loan ratio }\end{array}$ & $\begin{array}{l}\text { The } \\
\text { percentage } \\
\text { of } \\
\text { non-interest } \\
\text { income }\end{array}$ & $\begin{array}{l}\text { The } \\
\text { weighted } \\
\text { average } \\
\text { return } \\
\text { on equity }\end{array}$ & $\begin{array}{l}\text { The growth } \\
\text { rate of the } \\
\text { percentage } \\
\text { non-interest } \\
\text { income }\end{array}$ & $\begin{array}{l}\text { The growth } \\
\text { rate of the } \\
\text { weighted } \\
\text { average } \\
\text { return on } \\
\text { equity }\end{array}$ \\
\hline \multirow{3}{*}{ CCITICB } & 2013 & 9.05 & 1.03 & 3.41 & 206.62 & 73.21 & 18.05 & 18.48 & 15.71 & 10.66 \\
\hline & 2011 & 9.91 & 0.60 & 3.78 & 272.31 & 72.97 & 15.39 & 21.07 & 12.50 & 9.51 \\
\hline & 2009 & 9.17 & 0.95 & 5.76 & 149.36 & 79.62 & 11.81 & 12.71 & 16.70 & -17.47 \\
\hline \multirow{3}{*}{ BOC } & 2013 & 10.73 & 0.96 & 2.10 & 229.35 & 72.52 & 30.41 & 18.04 & 2.02 & -0.50 \\
\hline & 2011 & 10.07 & 1.00 & 3.10 & 220.75 & 68.77 & 30.50 & 18.27 & 1.90 & -3.18 \\
\hline & 2009 & 9.07 & 1.52 & 3.80 & 151.17 & 70.30 & 31.58 & 16.48 & 10.30 & 15.57 \\
\hline \multirow{3}{*}{$\mathrm{ABC}$} & 2013 & 9.81 & 1.22 & 3.33 & 367.04 & 61.17 & 18.68 & 20.89 & -1.57 & 0.72 \\
\hline & 2011 & 9.50 & 1.55 & 2.80 & 263.10 & 58.50 & 18.67 & 20.46 & 12.35 & -9.03 \\
\hline & 2009 & 7.74 & 2.91 & 4.44 & 105.37 & 55.19 & 18.28 & 20.53 & 122.61 & 15.86 \\
\hline \multirow{3}{*}{ CMSB } & 2013 & 8.83 & 0.85 & 2.59 & 259.74 & 73.39 & 28.35 & 23.23 & 12.61 & -7.96 \\
\hline & 2011 & 7.87 & 0.63 & 3.86 & 357.29 & 72.85 & 21.30 & 23.95 & 31.17 & 30.95 \\
\hline & 2009 & 8.92 & 0.84 & 6.50 & 206.04 & 75.38 & 23.35 & 20.19 & 76.31 & 32.57 \\
\hline \multirow{3}{*}{ ССВ } & 2013 & 11.14 & 0.99 & 4.51 & 268.22 & 70.28 & 23.41 & 21.23 & 0.29 & -3.41 \\
\hline & 2011 & 10.97 & 1.09 & 3.30 & 241.44 & 65.05 & 23.30 & 22.51 & 4.70 & -0.44 \\
\hline & 2009 & 9.31 & 1.50 & 3.09 & 175.77 & 60.24 & 20.70 & 20.87 & 30.03 & 0.92 \\
\hline \multirow{3}{*}{ CEB } & 2013 & 9.63 & 0.86 & 3.70 & 241.02 & 72.59 & 22.12 & 21.48 & 37.28 & -4.70 \\
\hline & 2011 & 7.89 & 0.64 & 5.58 & 367.00 & 71.67 & 14.40 & 20.44 & 0.13 & -2.62 \\
\hline & 2009 & 6.84 & 1.25 & 5.67 & 194.69 & 78.15 & 19.20 & 19.43 & 99.96 & -23.08 \\
\hline \multirow{3}{*}{ ICIB } & 2013 & 10.62 & 0.94 & 4.20 & 257.19 & 66.60 & 24.80 & 21.92 & 11.71 & -4.78 \\
\hline & 2011 & 10.07 & 0.94 & 3.60 & 266.92 & 63.50 & 23.70 & 23.44 & 17.10 & 2.85 \\
\hline & 2009 & 9.90 & 1.54 & 2.80 & 164.41 & 59.50 & 20.56 & 20.14 & 15.77 & 3.87 \\
\hline \multirow{3}{*}{ CMBC } & 2013 & 9.14 & 0.83 & 2.23 & 266.00 & 74.44 & 25.41 & 23.12 & 15.25 & -6.70 \\
\hline & 2011 & 8.22 & 0.56 & 3.43 & 400.13 & 71.80 & 20.64 & 24.17 & 3.01 & 11.13 \\
\hline & 2009 & 6.63 & 0.82 & 5.70 & 246.66 & 73.69 & 21.54 & 21.18 & 41.43 & -22.73 \\
\hline \multirow{3}{*}{ CIB } & 2013 & 9.21 & 0.76 & 7.06 & 352.10 & 62.53 & 21.45 & 22.39 & 21.83 & -15.98 \\
\hline & 2011 & 8.20 & 0.38 & 4.45 & 385.30 & 71.46 & 15.26 & 24.67 & 22.27 & 0.12 \\
\hline & 2009 & 7.91 & 0.54 & 6.53 & 254.93 & 71.90 & 14.13 & 24.54 & 19.20 & -5.83 \\
\hline \multirow{3}{*}{ SPDB } & 2013 & 8.64 & 0.74 & 1.92 & 319.65 & 73.05 & 14.84 & 21.53 & 28.37 & 2.77 \\
\hline & 2011 & 9.20 & 0.44 & 2.65 & 499.60 & 71.93 & 9.54 & 20.07 & 2.25 & -13.75 \\
\hline & 2009 & 6.90 & 0.80 & 3.35 & 245.93 & 71.71 & 8.92 & 25.86 & 1.85 & -29.56 \\
\hline \multirow{3}{*}{ PAB } & 2013 & 9.41 & 0.89 & 4.73 & 201.06 & 68.64 & 22.04 & 16.57 & 30.48 & -1.25 \\
\hline & 2011 & 8.46 & 0.53 & 3.71 & 320.66 & 72.94 & 14.69 & 18.35 & 20.68 & -21.31 \\
\hline & 2009 & 5.52 & 0.68 & 7.84 & 161.84 & 69.12 & 14.09 & 26.67 & 6.79 & 517.36 \\
\hline
\end{tabular}




\begin{tabular}{|c|c|c|c|c|c|c|c|c|c|c|}
\hline \multicolumn{11}{|l|}{ Continued } \\
\hline \multirow{3}{*}{ NBCB } & 2013 & 10.16 & 0.89 & 3.08 & 254.88 & 61.97 & 11.78 & 20.41 & 8.13 & 2.20 \\
\hline & 2011 & 12.17 & 0.68 & 2.17 & 240.74 & 66.62 & 14.22 & 18.81 & 5.47 & -8.38 \\
\hline & 2009 & 9.58 & 0.79 & 4.79 & 170.06 & 69.40 & 14.89 & 15.79 & -1.23 & -0.75 \\
\hline \multirow{3}{*}{ NJCB } & 2013 & 10.70 & 0.89 & 3.46 & 298.51 & 56.49 & 13.19 & 17.56 & -15.28 & 1.21 \\
\hline & 2011 & 11.76 & 0.78 & 2.28 & 323.98 & 61.77 & 12.74 & 15.87 & -1.13 & -7.79 \\
\hline & 2009 & 12.77 & 1.22 & 5.98 & 173.74 & 64.00 & 12.70 & 13.23 & -34.75 & -3.50 \\
\hline \multirow{3}{*}{ ВОСОМ } & 2013 & 9.76 & 1.05 & 1.55 & 213.65 & 73.40 & 20.54 & 15.49 & 11.22 & -15.95 \\
\hline & 2011 & 9.27 & 0.86 & 2.21 & 256.37 & 71.94 & 19.18 & 20.49 & 3.93 & 2.04 \\
\hline & 2009 & 8.15 & 1.36 & 2.75 & 151.05 & 71.97 & 21.59 & 19.26 & 50.15 & -7.67 \\
\hline \multirow{3}{*}{ HXB } & 2013 & 8.47 & 0.90 & 5.59 & 301.53 & 69.90 & 13.97 & 19.30 & 25.34 & 4.32 \\
\hline & 2011 & 8.72 & 0.92 & 4.69 & 308.21 & 66.72 & 9.69 & 17.44 & 38.03 & -4.44 \\
\hline & 2009 & 6.84 & 1.50 & 4.79 & 166.84 & 70.97 & 7.72 & 13.04 & -67.00 & -28.47 \\
\hline \multirow{3}{*}{ BOBJ } & 2013 & 9.62 & 0.65 & 6.54 & 385.91 & 68.74 & 14.28 & 18.05 & 24.39 & -1.37 \\
\hline & 2011 & 9.59 & 0.53 & 5.86 & 446.39 & 64.41 & 9.44 & 19.00 & 27.58 & 11.76 \\
\hline & 2009 & 12.38 & 1.02 & 6.90 & 215.69 & 58.94 & 7.90 & 16.00 & -19.99 & -11.11 \\
\hline
\end{tabular}

The date are quoted from the WIND datebase and bank annual report, In September 2012, the former Shenzhen Development Bank and the former Ping'an Bank were merged as the present-day Ping'an Bank.

Table 3. Index weight for the coupling degree between financial supervision and financial innovation of commercial bank.

\begin{tabular}{|c|c|c|c|c|c|c|c|}
\hline \multirow{2}{*}{$\begin{array}{r}\text { Order } \\
\text { parameter } u_{i}\end{array}$} & \multirow{2}{*}{ Evaluation index } & \multicolumn{2}{|c|}{2009} & \multicolumn{2}{|c|}{2011} & \multicolumn{2}{|c|}{2013} \\
\hline & & $\lambda_{i}$ & $\lambda_{i j}$ & $\lambda_{i}$ & $\lambda_{i j}$ & $\lambda_{i}$ & $\lambda_{i j}$ \\
\hline \multirow{5}{*}{$\begin{array}{l}\text { Financial } \\
\text { Supervision }\end{array}$} & Core capital adequacy ratio & \multirow{5}{*}{0.5540} & 0.2006 & \multirow{5}{*}{0.5552} & 0.2005 & \multirow{5}{*}{0.5556} & 0.2002 \\
\hline & Non-performing loan ratio & & 0.1990 & & 0.1987 & & 0.1995 \\
\hline & Top single customer’s loan ratio & & 0.1999 & & 0.1991 & & 0.1993 \\
\hline & Provisioning coverage ratio & & 0.2000 & & 0.2006 & & 0.2005 \\
\hline & Deposit -to- loan ratio (RMB) & & 0.2005 & & 0.2010 & & 0.2012 \\
\hline \multirow{4}{*}{$\begin{array}{l}\text { Financial } \\
\text { Innovation }\end{array}$} & The percentage of non-interest income & \multirow{4}{*}{0.4460} & 0.2496 & & 0.2504 & \multirow{4}{*}{0.4444} & 0.2506 \\
\hline & The weighted net average return on equity & & 0.2490 & & 0.2491 & & 0.2496 \\
\hline & $\begin{array}{l}\text { The growth rate of the percentage } \\
\text { of non-interest income }\end{array}$ & & 0.2488 & 0.4448 & 0.2506 & & 0.2497 \\
\hline & $\begin{array}{l}\text { The growth rate of the weighted } \\
\text { average ruturn on equity }\end{array}$ & & 0.2526 & & 0.2500 & & 0.2501 \\
\hline
\end{tabular}

\section{Conclusion and Enlightenment}

Following conclusions can be drawn by calculating and analyzing coupling degree between financial supervision and financial innovation of 16 domestic A-stock listed commercial banks in 2009, 2011 and 2013.

Table 4 shows the difference of coupling degree between financial supervision and financial innovation of domestic commercial banks. Moreover, coupling degree is relatively low in whole. For example, the highest coupling degree of Industrial Bank in 2013 is 0.4999, China Construction Bank in 2011 is 0.5, and Minsheng Bank in 2009 is 0.4999, which are not up to the degree for high coordination coupling stage. Some commercial 
Table 4. Coupling degree between financial supervision and financial innovation of commercial bank.

\begin{tabular}{|c|c|c|c|c|c|c|c|c|c|}
\hline \multirow{2}{*}{ Commercial Banks } & \multicolumn{3}{|c|}{2009} & \multicolumn{3}{|c|}{2011} & \multicolumn{3}{|c|}{2013} \\
\hline & c & $u_{1}$ & $u_{2}$ & c & $u_{1}$ & $u_{2}$ & c & $u_{1}$ & $u_{2}$ \\
\hline CCITICB & 0.4492 & 0.4061 & 0.1582 & 0.4993 & 0.4058 & 0.4527 & 0.4632 & 0.2619 & 0.5780 \\
\hline BOC & 0.4986 & 0.5113 & 0.4391 & 0.4998 & 0.4032 & 0.4245 & 0.4989 & 0.4921 & 0.5603 \\
\hline $\mathrm{ABC}$ & 0.4954 & 0.3955 & 0.5197 & 0.4974 & 0.4726 & 0.3848 & 0.4987 & 0.5642 & 0.4889 \\
\hline CMSB & 0.4999 & 0.4899 & 0.5137 & 0.4607 & 0.3640 & 0.8265 & 0.4819 & 0.3936 & 0.6802 \\
\hline ССВ & 0.4876 & 0.6630 & 0.4227 & 0.5000 & 0.4857 & 0.4899 & 0.4996 & 0.4925 & 0.5335 \\
\hline CEB & 0.4983 & 0.3926 & 0.4620 & 0.5000 & 0.2939 & 0.2858 & 0.4820 & 0.3986 & 0.6878 \\
\hline ICIB & 0.4816 & 0.6782 & 0.3909 & 0.4969 & 0.4929 & 0.6162 & 0.4979 & 0.5115 & 0.6159 \\
\hline CMBC & 0.4980 & 0.5278 & 0.4411 & 0.4981 & 0.4609 & 0.5499 & 0.4889 & 0.4319 & 0.6615 \\
\hline CIB & 0.4917 & 0.5799 & 0.4021 & 0.4950 & 0.4295 & 0.5707 & 0.4999 & 0.5139 & 0.5289 \\
\hline SPDB & 0.4749 & 0.6445 & 0.3375 & 0.4128 & 0.6388 & 0.1780 & 0.4977 & 0.5109 & 0.6193 \\
\hline PAB & 0.4751 & 0.3489 & 0.6651 & 0.4921 & 0.3890 & 0.2722 & 0.4873 & 0.3353 & 0.5284 \\
\hline NBCB & 0.4506 & 0.5805 & 0.2295 & 0.4456 & 0.6499 & 0.2443 & 0.4951 & 0.5844 & 0.4406 \\
\hline NJCB & 0.3611 & 0.6352 & 0.1157 & 0.3295 & 0.7352 & 0.1040 & 0.4362 & 0.7199 & 0.2472 \\
\hline BOCOM & 0.4972 & 0.5267 & 0.4258 & 0.4997 & 0.4193 & 0.3908 & 0.4879 & 0.3809 & 0.2440 \\
\hline HXB & 0.1204 & 0.4279 & 0.0064 & 0.4998 & 0.3595 & 0.3788 & 0.4848 & 0.3251 & 0.5359 \\
\hline BOBJ & 0.3638 & 0.7027 & 0.1308 & 0.4971 & 0.5347 & 0.4306 & 0.4960 & 0.5690 & 0.4419 \\
\hline Total & 7.1434 & 8.5107 & 5.6603 & 7.6238 & 7.5349 & 6.5997 & 7.796 & 7.4857 & 8.3923 \\
\hline
\end{tabular}

banks with relatively lowcoupling degree are in low coordination coupling stage, while others are in middle coordination coupling stage. In general, the low coupling degree in whole explains that benign interactive coupling mechanism has not been formed when domestic A-stock listed commercial banks coordinate financial supervision and financial innovation.

Table 4 shows that for domestic commercial banks, the order parameter of financial supervision is different from that of financial innovation in different stages. For example, the order parameter of financial supervision in 2009 and 2011 is larger than that of financial innovation for commercial banks, such as Bank of Nanjing. However, the order parameter of financial innovation is larger than that of financial supervision in 2013 for banks, such as Zhongxin Bank. This shows that financial supervision is targeted. Therefore, corresponding supervision strategies shall be taken for different kinds of financial innovation of commercial banks according to economic development in different stages.

Figure 1 shows that the coupling degree between financial supervision and financial innovation of domestic A-stock listed commercial banks increased in the whole from 2009 to 2013, and the coupling relationship between both is developing with benign interaction. This trend can also be seen from healthy and order development of domestic banking, improving financial supervision system and constantly enhancing innovative capacity of commercial banks.

In order to drive the healthy and order development of commercial banking, improve the coupling degree between financial supervision and financial innovation of commercial banks, a warning index system for financial supervision of commercial banks with coupling degree evaluation index system of capital quality, capital adequacy ratio, risk concentration, asset liquidity ratio, loss provision, etc. shall be established in principle of prudent operation of financial innovative subject to prevent and control financial risks.

Financial supervision system of commercial banks shall support financial innovation, deal with relationship between financial supervision and leading standard financial innovation, create a foreign financial environment promoting banking innovation, and support financial innovation of commercial banks in precondition of com- 


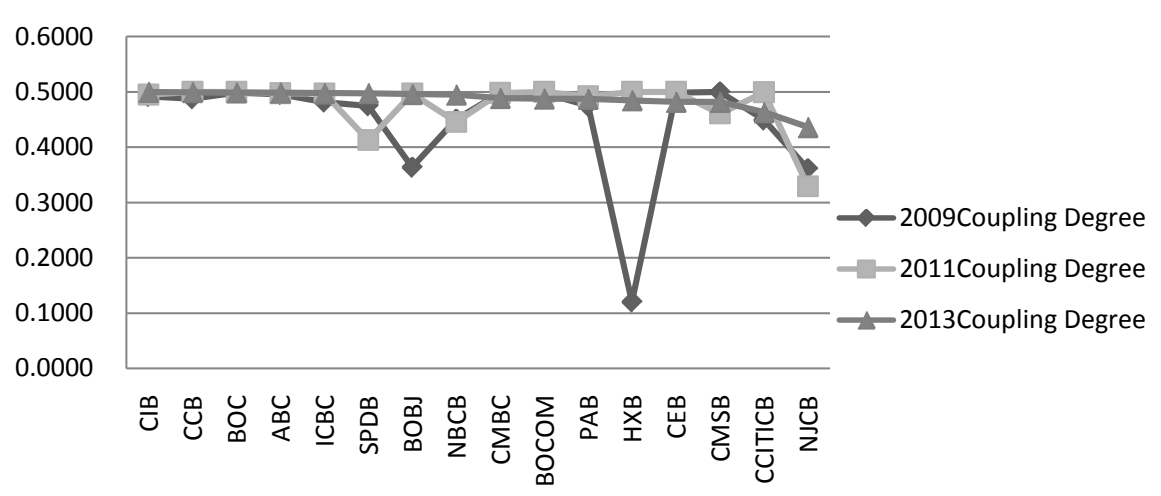

Figure 1. Coupling relation between financial supervision and financial innovation of commercial bank.

plete inner control mechanism to promote healthy, stable and sustainable development of economy in China.

\section{Acknowledgements}

This work was supported by the National Natural Science Foundation of China under Grant Nos. 71202054, the Soft Science Research Project of Anhui Province of China under Grant Nos. 1402052002, and "the Fundamental Research Funds for the Central Universities”.

\section{Competing Interests}

Authors have declared that no competing interests exist.

\section{References}

CBRC Issued “Guidelines on Financial Innovation of Commercial Banks” and Explained Question and Answer. http://www.gov.cn/gzdt/2006-12/06/content_462773.htm

Dang, J. Z., \& Xiang, J. (2012). A Study of the “Carpal” Regulatory System Impacted on the Operation of China’s Commercial Banks. Fujian Finance, 1, 11-12.

Finnerty, J. D. (1993). An Overview of Corporation Securities Innovation. Journal of Applied Corporate Finance, 4, $23-39$.

Isik, I., \& Hassan, M. K. (2003). Financial Deregulation and Total Factor Productivity Change: An Empirical Study of Turkish Commercial Banks. Journal of Banking \& Finance, 27, 1455-1485.

Kane, E. J. (1981). Accelerating Inflation, Technological Innovation, and the Decreasing Effectiveness of Banking Regulation. Journal of Finance, 36, 355-367. http://dx.doi.org/10.1111/j.1540-6261.1981.tb00449.X

Li, Y. Y. (2004). Analysis of the Relationship between Financial Supervision and Innovation. New Finance, $2,41$.

Liang, S. X. (2002). Analysis of the Interactive Relationship between Financial Supervision and Innovation. Forum of World Economics \& Politics, 5, 45-46.

Miller, M. H. (1986). Financial Innovation: The Last Twenty Years and the Next. Journal of Financial and Quantitative Analysis, 21, 459-471. http://dx.doi.org/10.2307/2330693

Silber, W. L. (1983). The Process of Financial Innovation. The American Economic Review, 73, 89-95.

Sun, L. J., Xing, X. J., \& Zhou, D. Q. (2010). Improved Entropy Weighting Method. Statistics and Decision, 21, 153.

Weick, K. E. (1976). Educational Organizations as Loosely Coupled Systems. Administrative Science Quarterly, 21, 1-19. http://dx.doi.org/10.2307/2391875

Xun, T., \& Wang, S. (2002). Thinking of the Relationship between Financial Supervision and Innovation. China Finance, 9, 24.

Zheng, L. (2006). Dynamic Game between Financial Innovation and Supervision: Enlightenments to China's Financial Supervision. Collected Essays on Finance and Economics, 4, 55.

Zhu, M. X. (2013). An Empirical Study of Correlation between Innovative Capability and Risk Supervision of China's Listed Commercial Banks. Journal of Financial Development Research, 4, 62.

Zhu, Y. Y., \& Li, P. (2011). Foreign Strategic Investors and the Innovation Capacity of Domestic Banks: Evidence from 73 Commercial Banks. Review of Investment Studies, 329, 57. 
Scientific Research Publishing (SCIRP) is one of the largest Open Access journal publishers. It is currently publishing more than 200 open access, online, peer-reviewed journals covering a wide range of academic disciplines. SCIRP serves the worldwide academic communities and contributes to the progress and application of science with its publication.

Other selected journals from SCIRP are listed as below. Submit your manuscript to us via either submit@scirp.org or Online Submission Portal.
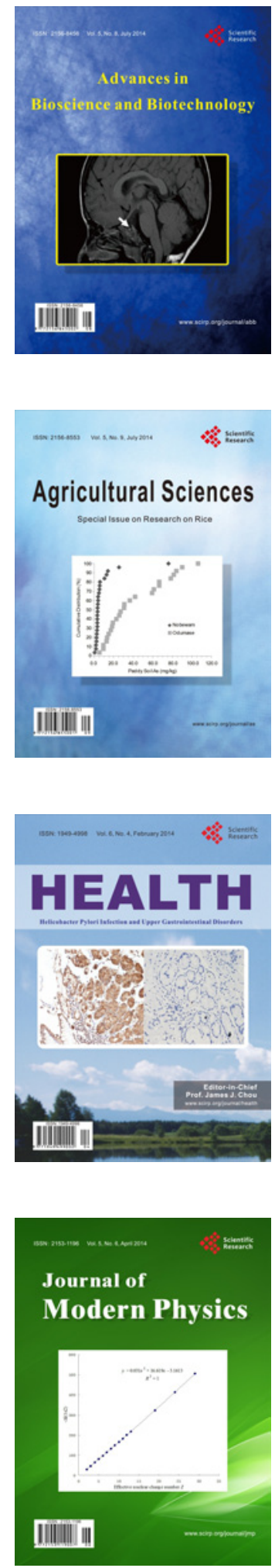
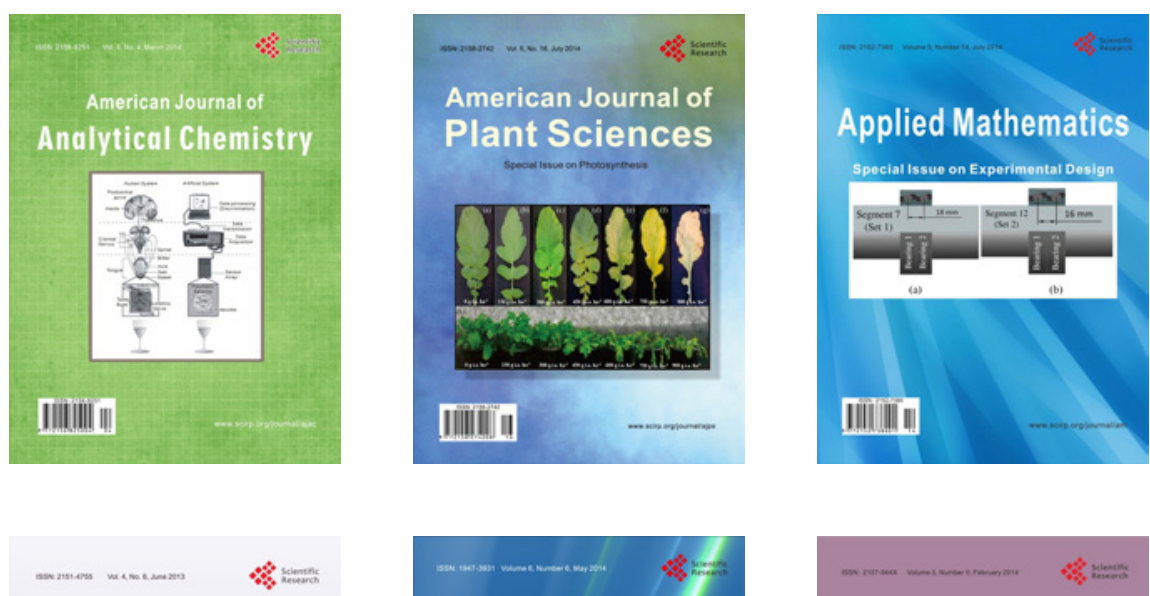

Creative Education
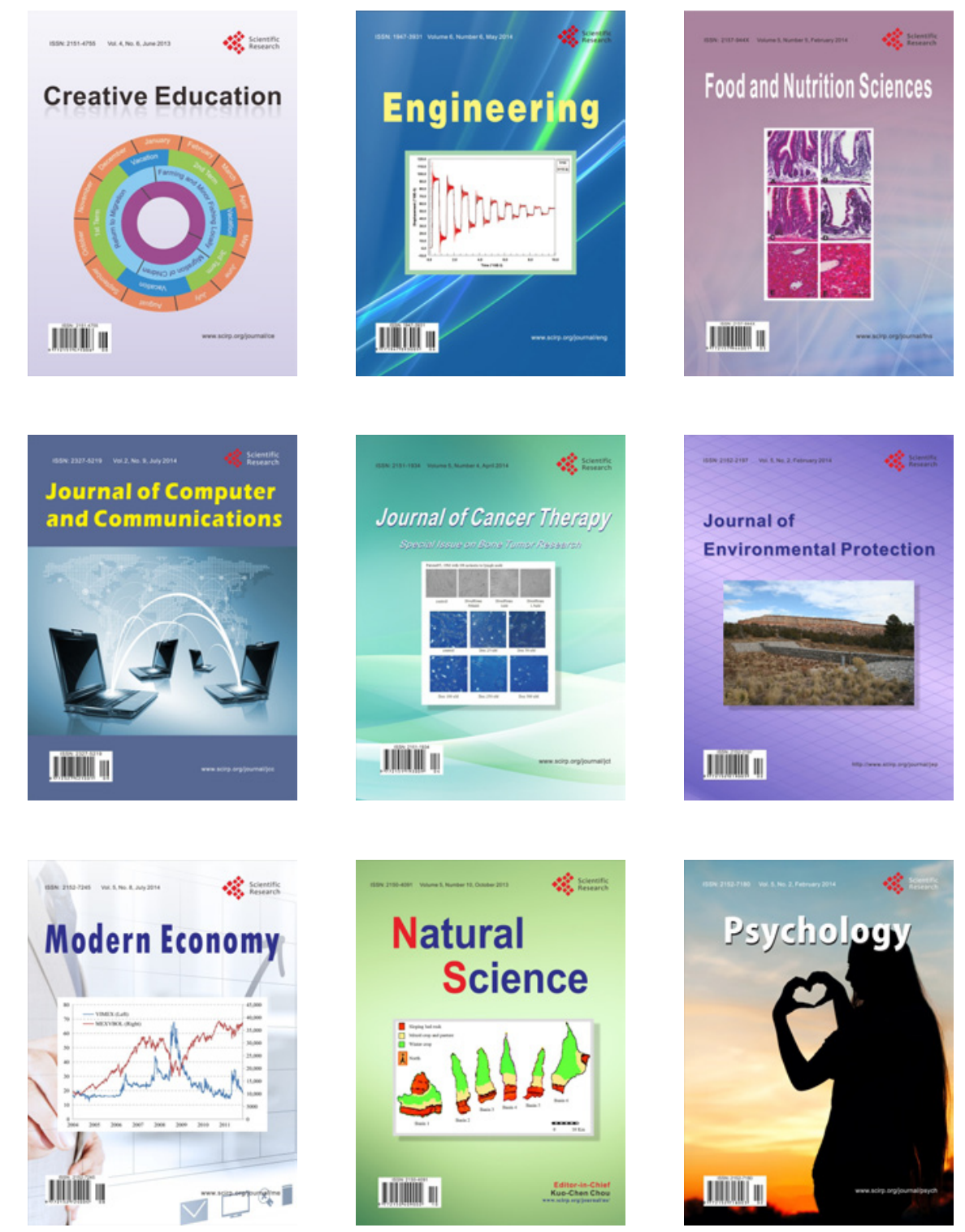